\title{
Tiotropium HandiHaler ${ }^{\circledR}$ in the treatment of COPD:A safety review
}

This article was published in the following Dove Press journal:

International Journal of COPD

27 October 2009

Number of times this article has been viewed

\author{
Steven Kesten' \\ Bart Celli ${ }^{2}$ \\ Marc Decramer ${ }^{3}$ \\ Inge Leimer ${ }^{4}$ \\ Donald Tashkin ${ }^{5}$ \\ 'Boehringer Ingelheim \\ Pharmaceuticals; Ridgefield, CT, \\ USA $;{ }^{2}$ Caritas St. Elizabeth's \\ Medical Center, Boston, MA, USA; \\ ${ }^{3}$ University of Leuven, Leuven, \\ Belgium; ${ }^{4}$ Boehringer Ingelheim \\ $\mathrm{GmbH}$, Ingelheim, Germany; ${ }^{5}$ David \\ Geffen School of Medicine at UCLA, \\ Los Angeles, CA, USA
}

Correspondence: Steven Kesten

Boehringer-Ingelheim Pharmaceuticals, Inc., 900 Ridgebury Rd, Ridgefield, CT

06877-0368, USA

Tel + | 203 79| 5983

Fax +l 2038375983

Email steven.kesten@boehringer-

ingelheim.com
Background: Tiotropium is a long-acting inhaled anticholinergic developed for the treatment of chronic obstructive pulmonary disease (COPD) and has been available since 2002. We sought to update an evaluation of the safety of tiotropium in the HandiHaler ${ }^{\circledR}$ formulation as significant clinical trial data have become available over time.

Methods: Pooled analysis of adverse event reporting from phase III and IV tiotropium HandiHaler ${ }^{\circledR}$ clinical trials with the following characteristics was performed: randomized, double-blind, parallel group, placebo-controlled design, tiotropium $18 \mu \mathrm{g}$ once-daily dosing, COPD indication, duration of at least four weeks. Incidence rates by treatment group, rate differences (tiotropium-placebo), and $95 \%$ confidence intervals were determined.

Results: Twenty-six trials were identified involving 17,014 patients. Mean age was 65 years, mean forced expiratory volume in one second was $1.16 \mathrm{~L}$ (41\% predicted), $76 \%$ men. Total exposure to study drug was 11,958 patient-years (tiotropium) and 10,578 patient-years (placebo). Tiotropium was associated with a reduced risk (expressed as rate difference [95\% confidence interval] per 100 patients-years at risk) for an adverse event $(-17.5[-22.9,-12.2])$, serious adverse event $(-1.41[-2.81,-0.00])$ and a fatal event $(-0.63[-1.14,-0.12])$. A reduced risk was present for adverse events that were cardiac $(-0.79[-1.48,-0.09])$, lower respiratory $(-14.2[-17.0,-11.5])$ and for a composite endpoint of major adverse cardiovascular events $(-0.45[-0.85,-0.05])$. Typical expected inhaled anticholinergic effects such as dry mouth, constipation, and urinary difficulties were observed in the safety database.

Conclusion: The safety data review does not indicate an increased risk for death or cardiovascular morbidity during tiotropium treatment in patients with COPD.

Keywords: tiotropium, chronic obstructive pulmonary disease, safety, mortality

\section{Introduction}

Chronic obstructive pulmonary disease (COPD) is a progressive disorder that is a major cause of morbidity, disability, and death. Analyses of administrative claims databases confirm the increased risk of death due to COPD relative to a healthy population. ${ }^{1}$ Patients with advanced COPD will often die from progressive parenchymal destruction and/or structural narrowing of the small airways that leads to airflow limitation, hyperinflation, exacerbations and respiratory failure. Indeed, mortality has been shown to be related to the severity of disease using either a simple measure such as forced expiratory volume in one second $\left(\mathrm{FEV}_{1}\right)$ or to other disease measures such as exercise tolerance and disease specific quality of life measurements. ${ }^{2-5}$ Furthermore, a reduced $\mathrm{FEV}_{1}$ appears to be a risk factor for cardiac disease and is also accompanied by multiple comorbidities. ${ }^{6}$ However, it may be difficult to separate the independence 
of COPD as a risk factor for nonrespiratory causes of death from the general patient profile of the disease (ie, exposure to tobacco smoke, advanced age).

Patients with symptomatic COPD receive therapeutic interventions which should include avoidance of toxic exposures (mainly from cigarette smoking), preventive vaccinations and pharmacotherapy. ${ }^{7}$ Pharmacotherapy has been shown to provide meaningful physiologic and symptomatic benefit as well as improving important longer term clinical aspects of the disease, such as exercise tolerance, health-related quality of life and exacerbation reduction. ${ }^{7}$ Patients with COPD often receive multiple medications for their airway disease and for common comorbidities. The multiple potential interactions of COPD, comorbidities, and medications may result in unanticipated adverse events. Due to the higher risk in COPD for premature mortality and the prevalence of comorbidities, especially cardiovascular disease, it becomes prudent to continue to ascertain information regarding the safety of therapeutic interventions for COPD.

Inhaled anticholinergics have been considered as a firstline option for the treatment of symptomatic COPD since the initial introduction of ipratropium bromide over two decades ago. ${ }^{7,8}$ Tiotropium is the only once-daily inhaled anticholinergic and the only once-daily inhaled medication approved for use in COPD. Two drug product formulations have been investigated in clinical trials, a dry powder formulation delivered through the HandiHaler ${ }^{\circledR}$ inhalation device, and an aqueous solution, delivered via the Respimat ${ }^{\circledR}$ inhaler, a novel, propellant-free delivery system. A previous report described adverse events from a pooled analysis of 19 clinical trials with tiotropium HandiHaler ${ }^{\circledR}$, ${ }^{9}$ while a more recent report focused on cardiovascular safety from a database of HandiHaler ${ }^{\circledR}$ (26 trials) and Respimat ${ }^{\circledR}$ (four trials) ${ }^{10}$ (Table 1). Given that the HandiHaler ${ }^{\circledR}$ formulation is the only available form of tiotropium in the majority of countries where tiotropium can be prescribed (over 90 countries worldwide), the present report is a summary of data with tiotropium HandiHaler ${ }^{\circledR}$ in the treatment of COPD. The clinical trial data reviewed is from the subset of HandiHaler ${ }^{\circledR}$ studies described in the report by Celli and colleagues, which only focused on cardiovascular events. ${ }^{10}$ The purpose of this report is to review key safety data that will assist health care professionals in decisions regarding prescribing of tiotropium delivered via the HandiHaler ${ }^{\circledR}$.

\section{Methods}

\section{Study population}

The methodology used is similar to that described in the report by Celli and colleagues and Kesten and colleagues,
Table I Clinical trials included in the pooled Tiotropium HandiHaler ${ }^{\circledR}$ analysis

\begin{tabular}{|c|c|c|c|}
\hline BITrial Number & $\begin{array}{l}\text { Duration } \\
\text { (Weeks) }\end{array}$ & $\begin{array}{l}\text { Placebo } \\
\text { (\# treated } \\
\text { patients) }\end{array}$ & $\begin{array}{l}\text { Tiotropium } \\
\text { (\# treated } \\
\text { patients) }\end{array}$ \\
\hline $205.114-117$ & 48 & 191 & 279 \\
\hline $205.115-128$ & 48 & 180 & 271 \\
\hline 205.123 & 6 & 40 & 81 \\
\hline 205.124 & 4 & 30 & 65 \\
\hline 205.130 & 24 & 201 & 209 \\
\hline 205.137 & 24 & 199 & 193 \\
\hline 205.131 & 6 & 100 & 98 \\
\hline 205.214 & 48 & 510 & 500 \\
\hline 205.215 & 12 & 54 & 46 \\
\hline 205.218 & 4 & 41 & 40 \\
\hline 205.223 & 6 & 130 & $13 \mid$ \\
\hline 205.230 & 25 & 53 & 55 \\
\hline 205.235 & 210 & 3006 & 2986 \\
\hline 205.247 & 25 & 117 & 117 \\
\hline 205.256 & 36 & 288 & 266 \\
\hline 205.257 & 12 & 403 & 1236 \\
\hline 205.259 & 48 & 305 & 608 \\
\hline 205.266 & 24 & 915 & 914 \\
\hline 206.269 & 16 & 127 & 123 \\
\hline 205.270 & 52 & 73 & 69 \\
\hline 205.276 & 12 & 195 & 200 \\
\hline 205.281 & 12 & 117 & 107 \\
\hline 205.282 & 12 & 164 & 147 \\
\hline 205.284 & 12 & 96 & 100 \\
\hline 205.294 & 8 & 86 & 80 \\
\hline 205.301 & 12 & 244 & 228 \\
\hline
\end{tabular}

with the major difference being that rate differences rather than rate ratios are calculated. ${ }^{9,10}$

The pooled safety database consists of 26 phase III and IV HandiHaler ${ }^{\circledR}$ completed clinical trials as of March 2009 in the tiotropium (Boehringer Ingelheim $\mathrm{GmbH}$, Ingelheim, Germany) project database. For inclusion, all trials used a placebo-controlled, double-blind and parallel-group study design. Trials were restricted to studies of COPD of at least four weeks' duration. Trials of less than four weeks' duration were excluded as minimal adverse events are generally observed in such short-term trials, which may therefore not reflect an accurate incidence during chronic maintenance treatment. The Boehringer Ingelheim study numbers of the 26 trials of tiotropium were as follows: $205.114 / 117,{ }^{11} 205.115 / 128,{ }^{11} 205.123,{ }^{12} 205.124,{ }^{13}$ $205.130,{ }^{14} 205.131,{ }^{15} 205.137,{ }^{14} 205.214,{ }^{16} 205.215,{ }^{17}$ $205.218,{ }^{18} 205.223,{ }^{19} 205.230,{ }^{20} 205.235,{ }^{21} 205.247,{ }^{22}$ 
$205.256,{ }^{23} 205.257,{ }^{24} 205.259,{ }^{25} 205.266,{ }^{26} 205.269$, $205.270,{ }^{27} 205.276,{ }^{28} 205.281,{ }^{29} 205.282,{ }^{30} 205.284,{ }^{31}$ $205.294,,^{32}$ and $205.301 .{ }^{33}$

Trials used similar inclusion and exclusion criteria as previously described. ${ }^{9,10}$ In brief, inclusion criteria were: diagnosis of COPD, $\mathrm{FEV}_{1} \leq 70 \%$ of forced vital capacity (FVC), age $\geq 40$ years, $\geq 10$ pack-years of smoking. Exclusion criteria are summarized as follows: diagnosis of asthma, symptomatic prostatic hypertrophy or bladder neck obstruction, narrow-angle glaucoma, and known hypersensitivity to study medication or components. Significant disease other than COPD which could significantly confound the study results or preclude study completion was also an exclusion criterion. Other exclusion criteria in earlier trial protocols were heart failure resulting in a hospitalization in the previous three years, cardiac arrhythmia requiring drug treatment, or myocardial infarction within the past year. Nevertheless, heart failure and ischemic heart disease were not necessarily exclusion criteria. Changes in exclusion criteria in more recent trials such as UPLIFT were life-threatening cardiac arrhythmia or arrhythmia requiring a change in medication within the last year, heart failure resulting in hospitalization in the past year and myocardial infarction within the preceding six months. Written informed consent was obtained from all patients and ethics committee approval was obtained for all protocols.

Use of theophyllines, inhaled corticosteroids, modest daily doses of oral corticosteroids (provided the dosing was stable) and short-acting $\beta$-agonists were permitted in all trials. The four-year UPLIFT ${ }^{\circledR}$ trial $(5,992$ patients), trial 205.266 (1,829 patients), trials 205.259, 205.270, 205.282, and 205.284 also permitted use of long-acting $\beta$-agonists (LABAs) as prescribed. ${ }^{21,25,26,30,31}$

\section{Study variables}

Spirometry was performed in all studies according to accepted standards. ${ }^{34} \mathrm{~A}$ variety of efficacy endpoints were incorporated into individual protocols such as lung volumes, exercise testing, patient-reported outcome questionnaires and exacerbation of COPD. All study visits included collection of adverse events.

\section{Adverse event reporting}

Adverse events during the conduct of the trial were reported by the investigational sites to Boehringer Ingelheim. An adverse event was defined as any untoward medical occurrence occurring during the trial which did not necessarily have to have a causal relationship with the treatment. A serious adverse event was defined as any adverse event that resulted in death, was immediately lifethreatening, resulted in persistent or significant disability/ incapacity, required or prolonged patient hospitalization, or was deemed serious for any other reason representing a significant hazard, which is comparable to the aforementioned criteria. In trial 205.266, nonserious adverse events were $a$ priori not to be recorded. ${ }^{26}$ Adverse events, serious adverse events, and fatal adverse events are described separately.

All adverse events included in the analysis are from the period during which the patient received study drug for 30 days (defined as the period at risk) and as reported by the investigator. Vital status information was collected from patients who prematurely discontinued study medication only in the four-year UPLIFT trial and in trial 205.266 and is not included in the present analysis. ${ }^{10,26}$

\section{Categorization of adverse events}

The Medical Dictionary for Regulatory Activities (MedDRA) version 11.1 was used to code all adverse events. The dictionary includes quite specific terms, noted as preferred terms (PT). Each PT is categorized under organ classes, referred to as system organ classes (SOC) within MedDRA. Due to the needs of the tiotropium project, several of the SOCs from MedDRA were modified during the development program and are used for the present report. The preferred terms provide a very granular level of detail; however, the disadvantage of the granularity is that similar adverse event reports can be divided among many terms, which may lead to small numbers of events at a PT level. In order to improve the precision of the rate estimates for adverse events, similar PTs have been combined to capture clinical endpoints of interest. For example, the endpoint of stroke represents a composite of multiple PTs as there is no single PT noted as "stroke". There are 66 preferred terms including within stroke (eg, cerebrovascular accident, brain stem infarction, cerebral artery occlusion, cerebral artery embolism, cerebral artery thrombosis, hemorrhagic stroke). Tables include PTs or combined PTs under their specific organ system. An individual patient may be represented in several preferred terms or combined preferred terms but will only be represented once when the data is displayed according to the SOC (total). A similar approach has been used and is described in previous publications..$^{9,10}$

A composite endpoint of major adverse cardiovascular events was included in the analysis. The composite 
endpoint consists of fatal events in the SOC cardiac disorders and SOC vascular disorders along with myocardial infarction (fatal and nonfatal), stroke (fatal and nonfatal) and sudden death, sudden cardiac death and cardiac death. Nonfatal myocardial infarction and nonfatal stroke were removed for the composite endpoint of fatal cardiovascular events.

\section{Statistical methods}

The following definitions were used:

Total exposure time to study drug = total days from $1 \mathrm{st}$ dose to last dose of study drug.

Time at risk $=$ from 1 st administration of drug to 30 days following the last dose of study drug or until the onset of the specific adverse event analyzed, whichever came first.

Incidence rate (IR) = number of patients with an event/ cumulative time at risk within a treatment group.

Incidence rate difference $(\mathrm{RD})=\mathrm{IR}$ (tiotropium) $-\mathrm{IR}$ (placebo).

Incidence rate differences were estimated based on the method described by Greenland and Robins. ${ }^{35}$ The $95 \%$ confidence interval (CI) was calculated for each rate difference in order to describe the precision of the effect estimate. ${ }^{35} \mathrm{~A} \mathrm{RD}<0$ indicates a decreased risk with tiotropium and a RD $>0$ indicates a decreased risk with placebo. A $P$ value less than 0.05 is indicated when the width of the CI excludes the value 0 . Potential heterogeneity among trials for adverse events, serious adverse events, and fatal adverse events was explored prior to combining trials using Zelen's test. ${ }^{37}$

\section{Results}

\section{Study population}

The number of patients (patient-years of exposure) was 7,865 $(10,578)$ for placebo and 9,149 $(11,958)$ for tiotropium. Baseline demographics (Table 2) were balanced between treatment groups. A total of 4,508 (26.5\%) patients prematurely discontinued study medication with a higher discontinuation rate in the placebo than the tiotropium treated patients (30.9\% vs. $22.7 \%$, respectively). Zelen's test for adverse events $(P=0.42)$, serious adverse events $(P=1.00)$ and fatal adverse events $(P=1.00)$ did not indicate heterogeneity among the 26 HandiHaler $^{\circledR}$ trials.

Baseline (ie, taken at study entry) concomitant respiratory medication use was balanced between treatment groups. More than $50 \%$ of patients were receiving inhaled corticosteroids, $39 \%$ were receiving LABAs, and $22 \%$ were receiving theophyllines (Table 3 ).
Table 2 Baseline characteristics of patients in the placebo and tiotropium groups

\begin{tabular}{lll}
\hline Characteristic & $\begin{array}{l}\text { Placebo }(\mathbf{n} \\
\mathbf{9 7 , 8 6 5 )}\end{array}$ & $\begin{array}{l}\text { Tiotropium } \\
(\mathbf{n}=\mathbf{9 , 1 4 9 )}\end{array}$ \\
\hline Age (years)* & $64.7(8.9)$ & $64.5(8.8)$ \\
Male (\%) & 76.0 & 76.0 \\
Current smoker (\%) & 33.0 & 33.8 \\
Baseline spirometry & & \\
FEV,$(L) *$ & $1.15(0.46)$ & $1.17(0.47)$ \\
FEV (\% predicted)* & $40.8(14.1)$ & $41.3(14.3)$ \\
FVC (L)* & $2.50(0.82)$ & $2.47(0.81)$ \\
FEV,/FVC* & $0.47(0.12)$ & $0.48(0.13)$ \\
\hline
\end{tabular}

Note: *Mean (standard deviation).

Abbreviations: $\mathrm{FEV}_{1}$, forced expiratory volume in one second; FVC, forced vital capacity.

\section{Overall adverse events}

A majority of patients (62\%) experienced at least one adverse event during the trial, with a lower risk of experiencing an event in the tiotropium group as observed by the incidence RD (tiotropium minus placebo) of -18 patients per 100 patient-years at risk (Table 4). Reductions in risk were documented for serious adverse events (difference $=-1.4$ patients per 100 patient-years) and for fatal events (difference $=-0.6$ patients per 100 patient-years). All values excluded an upper limit of 0 in the CI.

\section{Cardiovascular and lower respiratory adverse events}

The results presented in this section include a list of pooled terms representing the cardiovascular and lower respiratory

Table 3 Baseline concomitant respiratory medications in the placebo and tiotropium groups

\begin{tabular}{|c|c|c|}
\hline & $\begin{array}{l}\text { Placebo } \\
(n=7,865) \\
n(\%)\end{array}$ & $\begin{array}{l}\text { Tiotropium } \\
(n=9,149) \\
n(\%)\end{array}$ \\
\hline Any respiratory medication & $6,637(84.4)$ & $7,499(82.0)$ \\
\hline Short-acting inhaled anticholinergics ${ }^{a}$ & $3,219(40.9)$ & $3,627(39.6)$ \\
\hline Long-acting inhaled anticholinergics & $91(1.2)$ & $94(1.0)$ \\
\hline Short-acting inhaled $\beta_{2}$-agonists ${ }^{a}$ & $2,823(35.9)$ & $3,396(37.1)$ \\
\hline Long-acting inhaled $\beta_{2}$-agonists ${ }^{\mathrm{b}}$ & $3,184(40.5)$ & $3,369(36.8)$ \\
\hline Inhaled corticosteroids ${ }^{\mathrm{b}}$ & $4,407(56.0)$ & $5,024(54.9)$ \\
\hline Oral steroids & $289(3.7)$ & $374(4.1)$ \\
\hline Theophylline compounds & I,685 (2I.4) & $2,076(22.7)$ \\
\hline Mucolytics & $40 \mathrm{I}(5.1)$ & $458(5.0)$ \\
\hline Leukotriene receptor antagonists & $176(2.2)$ & $189(2.1)$ \\
\hline Supplemental oxygen & $399(5.1)$ & $4 \mid 4(4.5)$ \\
\hline
\end{tabular}

Notes: Baseline period for medications is defined as time before consent date and ending after or equal to consent date. alone or in combination; balone or in combination. 
Table 4 Incidence rates and rate differences (tiotropium-placebo) per 100 patient-years for adverse events, serious adverse events and fatal adverse events

\begin{tabular}{|c|c|c|c|c|c|}
\hline & \multicolumn{2}{|c|}{ Placebo $(n=7,865)$} & \multicolumn{2}{|c|}{ Tiotropium $(n=9,149)$} & \multirow{2}{*}{$\begin{array}{l}\text { Tiotropium-placebo } \\
\text { RD }(95 \% \mathrm{Cl})\end{array}$} \\
\hline & $\bar{n}$ & IR & $\bar{n}$ & IR & \\
\hline Adverse events & 5071 & 145.3 & 5560 & 133.1 & $-17.5(-22.9,-12.2)^{*}$ \\
\hline Serious adverse events & 2088 & 24.1 & 2237 & 22.6 & $-1.4 \mid(-2.81,-0.00)^{*}$ \\
\hline Fatal adverse events & 472 & 4.27 & 445 & 3.55 & $-0.63(-1.14,-0.12)^{*}$ \\
\hline
\end{tabular}

Abbreviations: $\mathrm{Cl}$, confidence interval; n, number of patients with an event; IR, incidence rate (per 100 patient-years of time at risk); RD, rate difference ( $95 \% \mathrm{Cl}$ ) per 100 patient-years of time at risk, $* P<0.05$.

terms and categories of particular interest. The selection was based on clinical categories that are of public health interest or on possible pathophysiologic associations suggested by either previous published reports or potential biologic mechanisms. Individual patients may be represented in multiple categories, but a patient is only represented once within a category or at the SOC level (ie, cardiac disorder SOC total). For example, all patients reported to have a myocardial infarction would be counted with the pooled term "ischemic heart disease."

Overall, there were 1,511 patients with at least one cardiac adverse event and 1,233 patients with at least one vascular adverse event (Table 5). The RD (95\% CI) for any cardiac event (tiotropium minus placebo) was -0.79
$(-1.48,-0.09)$ and for any vascular event was -0.14 $(-0.77,0.49)$. Tiotropium was associated with a decreased risk for a cardiac adverse event and no increased risk for a vascular adverse event. The absence of increased risk was observed for the most common events in the categories of hypertension, ischemic heart disease and cardiac failure. Cardiac failure occurred at a decreased rate with tiotropium relative to placebo $(\mathrm{RD}(95 \% \mathrm{CI})=-0.47(-0.84,-0.10)$. For myocardial infarction and stroke, the RDs $(95 \% \mathrm{CI})$ were $-0.18(-0.42$, $0.05)$ and $0.04(-0.20,0.27)$, respectively. The incidence rates for stroke were similar between the two treatment arms. There was no indication of an increased risk for myocardial infarction or stroke associated with tiotropium.

Table 5 Incidence rates and rate differences (tiotropium-placebo) per 100 patient-years for adverse events according to selected organ systems and adverse event endpoints

\begin{tabular}{|c|c|c|c|c|c|}
\hline & \multicolumn{2}{|c|}{ Placebo $(n=7,865)$} & \multicolumn{2}{|c|}{ Tiotropium $(n=9,149)$} & \multirow{2}{*}{$\begin{array}{l}\text { Tiotropium-Placebc } \\
\text { RD }(95 \% \mathrm{Cl})\end{array}$} \\
\hline & $\bar{n}$ & IR & $\mathbf{N}$ & $\overline{\text { IR }}$ & \\
\hline Cardiac disorders & 750 & 7.26 & 761 & 6.47 & $-0.79(-1.48,-0.09)^{*}$ \\
\hline Atrial fibrillation/flutter & $14 \mid$ & 1.27 & 143 & 1.14 & $-0.12(-0.40,0.17)$ \\
\hline Cardiac arrest & 31 & 0.28 & 22 & 0.17 & $-0.09(-0.22,0.03)$ \\
\hline Cardiac failure & 254 & 2.32 & 229 & 1.83 & $-0.47(-0.84,-0.10)^{*}$ \\
\hline Ischemic heart disease & 279 & 2.56 & 282 & 2.29 & $-0.28(-0.69,0.12)$ \\
\hline Myocardial infarction & 105 & 0.94 & 95 & 0.75 & $-0.18(-0.42,0.05)$ \\
\hline Palpitations & 54 & 0.48 & 67 & 0.53 & $0.04(-0.14,0.22)$ \\
\hline Supraventricular tachycardia & 25 & 0.22 & 32 & 0.25 & $0.03(-0.09,0.16)$ \\
\hline Tachycardia (nonventricular) & 49 & 0.44 & 60 & 0.48 & $0.02(-0.15,0.19)$ \\
\hline Ventricular tachycardia/fibrillation & 27 & 0.24 & 19 & 0.15 & $-0.09(-0.20,0.03)$ \\
\hline Vascular disorders & 588 & 5.68 & 645 & 5.50 & $-0.14(-0.77,0.49)$ \\
\hline Aneurysm & 40 & 0.36 & 51 & 0.40 & $0.05(-0.10,0.2 I)$ \\
\hline Hypertension & 368 & 3.47 & 379 & 3.13 & $-0.34(-0.82,0.13)$ \\
\hline Stroke & 94 & 0.85 & 109 & 0.87 & $0.04(-0.20,0.27)$ \\
\hline Lower respiratory disorders & 3648 & 65.02 & 3716 & 53.16 & $-14.2(-17.0,-11.5)^{*}$ \\
\hline COPD exacerbation & 2829 & 43.18 & 2793 & 34.87 & $-8.90(-11.0,-6.83)^{*}$ \\
\hline Pneumonia & 525 & 4.96 & 572 & 4.78 & $-0.25(-0.83,0.33)$ \\
\hline Respiratory failure & 209 & 1.89 & 183 & 1.46 & $-0.38(-0.7 \mathrm{I},-0.05)^{*}$ \\
\hline
\end{tabular}

Abbreviations: $\mathrm{Cl}$, confidence interval; COPD, chronic obstructive pulmonary disease; $n$, number of patients with an event; IR, incidence rate (per I00 patient-years of time at risk); RD $(95 \% \mathrm{Cl})$, rate difference $(95 \% \mathrm{Cl})$ per 100 patient-years of time at risk; terms used are composed of multiple MedDRA-preferred terms; $* \mathrm{P}<0.05$. 
Lower respiratory tract events were common and occurred with a lower rate in the tiotropium group (RDs, $-14.2 ; 95 \%$ $\mathrm{CI}:-17.0,-11.5)$. The most common event was reported as a COPD exacerbation, which along with respiratory failure, occurred with a tiotropium minus placebo rate difference and upper limit of the CI below zero.

There were 899 patients with at least one serious cardiac event and 274 with at least one serious vascular event (Table 6). The RD $(95 \% \mathrm{CI})$ for any serious cardiac event (tiotropiumplacebo) was $-0.79(-1.30,-0.27)$ and $0.14(-0.13,0.42)$ for any serious vascular event. Tiotropium was not associated with a significantly increased risk for either a cardiac or vascular serious adverse event, including the most common events in the categories of ischemic heart disease and cardiac failure. The incidence rate for serious events reported as ischemic heart disease was lower with tiotropium and there was a trend for a reduced rate for cardiac failure. For serious myocardial infarction and stroke, the RDs $(95 \% \mathrm{CI})$ were $-0.18(-0.41,0.05)$ and $0.07(-0.14,0.29)$, respectively.

Lower respiratory tract serious adverse events were common and occurred with a lower rate in the tiotropium group (RDs -2.23 ; 95\% CI: $-3.20,-1.27$ ). The most common event was reported as a COPD exacerbation, which, along with respiratory failure, occurred with a rate difference and upper limit of the CI below zero in the tiotropium group.

\section{Major adverse cardiovascular event}

The incidence rates and rate differences for the composite endpoint of a major adverse cardiovascular event are displayed in Table 7. There was a lower incidence rate for a major cardiovascular event in the tiotropium group relative to the placebo group ( -0.45 patients per 100 patient-years at risk) and a lower rate for fatal cardiovascular events $(-0.32$ patients per 100 patient-years at risk). A further analysis was performed that includes the nonspecific preferred term "death" (used when a cause of death could not be determined) assuming that the cause of death in all cases was cardiovascular. For this expanded endpoint, the rate difference remained less than 0 ( $\mathrm{RD}=-0.28$; 95\% $\mathrm{CI}$ : $-0.58,0.02)$.

\section{Anticholinergic events}

Anticholinergic medications are known to exert pharmacologic effects on multiple organ systems. Inhaled quaternary anticholinergics do not cross the blood brain barrier to any relevant extent and appear to be devoid of central nervous system effects. Tables 8 and 9 document

Table 6 Incidence rates and rate differences (tiotropium-placebo) per 100 patient-years for serious adverse events cases according to selected organ systems and adverse event endpoints

\begin{tabular}{|c|c|c|c|c|c|}
\hline & \multicolumn{2}{|c|}{ Placebo $(n=7,865)$} & \multicolumn{2}{|c|}{ Tiotropium $(n=9,149)$} & \multirow{2}{*}{$\begin{array}{l}\text { Tiotropium-placebo } \\
\text { RD }(95 \% \mathrm{Cl})\end{array}$} \\
\hline & $\overline{\mathbf{N}}$ & IR & $\bar{n}$ & IR & \\
\hline Cardiac disorders & 466 & 4.33 & 433 & 3.53 & $-0.79(-1.30,-0.27)^{*}$ \\
\hline Ischemic heart disease* & 196 & 1.78 & 181 & 1.45 & $-0.34(-0.67,-0.01)^{*}$ \\
\hline Atrial fibrillation/flutter & 84 & 0.75 & 81 & 0.64 & $-0.10(-0.32,0.11)$ \\
\hline Cardiac arrest & 30 & 0.27 & 22 & 0.17 & $-0.09(-0.21,0.03)$ \\
\hline Cardiac failure & 165 & 1.49 & 154 & 1.22 & $-0.26(-0.56,0.04)$ \\
\hline Myocardial infarction & 102 & 0.92 & 92 & 0.73 & $-0.18(-0.41,0.05)$ \\
\hline Palpitations & 5 & 0.04 & 6 & 0.05 & $0.00(-0.05,0.05)$ \\
\hline Supraventricular tachycardia & 13 & 0.12 & 15 & 0.12 & $0.01(-0.08,0.09)$ \\
\hline Tachycardia (nonventricular) & 6 & 0.05 & 7 & 0.06 & $-0.01(-0.06,0.05)$ \\
\hline Ventricular tachycardia/fibrillation & 21 & 0.19 & 17 & 0.13 & $-0.05(-0.15,0.05)$ \\
\hline Vascular disorders & 122 & 1.10 & 152 & 1.21 & $0.14(-0.13,0.42)$ \\
\hline Aneurysm & 27 & 0.24 & 31 & 0.24 & $0.01(-0.12,0.14)$ \\
\hline Hypertension & 21 & 0.19 & 16 & 0.13 & $-0.06(-0.16,0.04)$ \\
\hline Stroke & 74 & 0.66 & 91 & 0.72 & $0.07(-0.14,0.29)$ \\
\hline Lower respiratory disorders & 1301 & 13.4 & 1265 & 11.3 & $-2.23(-3.20,-1.27)^{*}$ \\
\hline COPD exacerbation & 951 & 9.44 & 921 & 7.95 & $-1.58(-2.37,-0.78)^{*}$ \\
\hline Pneumonia & 370 & 3.41 & 390 & 3.18 & $-0.26(-0.73,0.22)$ \\
\hline Respiratory failure & 189 & 1.71 & 158 & 1.25 & $-0.40(-0.72,-0.09)^{*}$ \\
\hline
\end{tabular}

Abbreviations: $\mathrm{Cl}$, confidence interval; COPD, chronic obstructive pulmonary disease; $\mathrm{n}$, number of patients with an event; IR, incidence rate (per I00 patient-years of time at risk); RD $(95 \% \mathrm{Cl})$, rate difference $(95 \% \mathrm{Cl})$ per 100 patient-years of time at risk; terms used are composed of multiple MedDRA-preferred terms; $* \mathrm{P}<0.05$. 
Table 7 Incidence rates and rate differences (tiotropium-placebo) per 100 patient-years for a major adverse cardiovascular event

\begin{tabular}{|c|c|c|c|c|c|}
\hline & \multicolumn{2}{|c|}{ Placebo $(n=7,865)$} & \multicolumn{2}{|c|}{ Tiotropium $(n=9,149)$} & \multirow{2}{*}{$\begin{array}{l}\text { Tiotropium-placebo } \\
\text { RD }(95 \% \mathrm{Cl})\end{array}$} \\
\hline & n & IR & $n$ & IR & \\
\hline Major adverse CV event & 297 & 2.71 & 277 & 2.22 & $-0.45(-0.85,-0.05)^{*}$ \\
\hline Fatal CV event & 145 & 1.30 & 121 & 0.96 & $-0.32(-0.59,-0.05)^{*}$ \\
\hline
\end{tabular}

Abbreviations: $\mathrm{Cl}$, confidence interval; $\mathrm{CV}$, cardiovascular; n, number of patients with an event; IR, incidence rate (per 100 patient-years of time at risk); RD ( $95 \% \mathrm{Cl}$ ), rate difference $(95 \% \mathrm{Cl})$ per 100 patient-years of time at risk; terms used are composed of multiple MedDRA-preferred terms; $* P<0.05$.

the adverse event and serious adverse event reported incidence rates and rate differences for presumed, potential or hypothetical events that may be a consequence of anticholinergic pharmacology. Cardiovascular and lower respiratory events are noted in the preceding tables and are not repeated in Tables 8 and 9. As with the previous analysis, similar preferred terms have been combined to increase the absolute numbers and improve the precision of the estimated rates and RDs.

Typical expected inhaled anticholinergic effects such as dry mouth, constipation, and urinary difficulties were observed in the safety database. Dry mouth was the most common event and showed the largest rate difference $(\mathrm{RD}=1.65 ; 95 \% \mathrm{CI}: 1.28,2.03)$. Additionally, under gastrointestinal disorders, higher incidence rates were observed for dyspepsia, gastroesophageal reflux, and gastrointestinal obstruction. For renal and urinary disorders, higher incidence rates with tiotropium were observed for dysuria and urinary retention. A higher risk of pharyngitis was reported with tiotropium, which may reflect reporting related to drying of the upper airways. There were no overall imbalances with regard to nervous system disorders, psychiatric disorders, and metabolism disorders.

\section{Fatal events}

As noted, there was a lower incidence rate for a fatal event during treatment in the tiotropium HandiHaler ${ }^{\circledR}$ group relative to the placebo group, with the upper limit of the CI being less than zero. A Forest plot of the rate differences for the individual trials is displayed in Figure 1. The overall analysis is dominated by the UPLIFT trial. Most of the individual trials are associated with wide CIs, a few of which have incidence rates that are higher in the tiotropium group.

Causes of death are presented according to system organ class where the frequency is at least $3 \%$ of the total number of deaths in either treatment period (Table 10). As expected, the most common causes of death occurred in the system organ classes of lower respiratory and cardiac. In all cases there was no imbalance indicating an excess risk with tiotropium.
Causes of death according to preferred terms based on a frequency of at least 10 events in a treatment group are displayed in Table 11. The most common causes of death were reported as COPD exacerbation, respiratory failure and pneumonia. The events where the upper limit of the CI was less than zero were respiratory failure and sepsis.

\section{Discussion}

Tiotropium HandiHaler ${ }^{\circledR}$ was introduced in Europe in 2002 and over the subsequent years has become available in over 90 countries. Tiotropium HandiHaler ${ }^{\circledR}$ has been demonstrated to be effective in the treatment of COPD with numerous published randomized, double-blind, controlled clinical trials showing improvements in airflow, air trapping, hyperinflation, symptoms such as breathlessness (as measured by questionnaires and requirement for rescue short-acting $\beta$-agonists), exercise duration during cycle and treadmill exercise testing, health-related quality of life (as measured by the St. George's Respiratory Questionnaire) and exacerbations. ${ }^{11,14-21,23-27}$ The safety profile of tiotropium is generally related to anticholinergic mechanisms although other events are noted in package inserts based on imbalances in clinical trials where a potential mechanism is uncertain.

Additional data regarding safety may be uncovered through evaluation of peer-reviewed scientific publications. Such safety data tend to be based on relatively small numbers of patients participating in a single clinical trial or based on isolated case reports or case series. Data has previously been published on a pooled analysis of 19 clinical trials $;{ }^{9}$ however, the largest clinical trial of tiotropium, UPLIFT, had not yet been completed. ${ }^{21} \mathrm{~A}$ recent publication regarding safety focused on cardiovascular adverse events from a 30-trial database including two formulations of tiotropium. ${ }^{10}$ The present document more than doubles the sample size in the 19 trial publication (total of 7,819 patients) but is restricted to the 26 HandiHaler ${ }^{\circledR}$ formulation trials in the publication by Celli and colleagues, as the other formulation is not as widely available as the HandiHaler ${ }^{\circledR}$ formulation. ${ }^{10}$ Furthermore, while cardiovascular safety data has been presented by Celli and 
Table 8 Incidence rates and rate differences (tiotropium-placebo) per 100 patient-years for potential anticholinergic adverse events

\begin{tabular}{|c|c|c|c|c|c|}
\hline & \multicolumn{2}{|c|}{ Placebo $(n=7,865)$} & \multicolumn{2}{|c|}{ Tiotropium $(n=9,149)$} & \multirow{2}{*}{$\begin{array}{l}\text { Tiotropium-Placebo } \\
\text { RD }(95 \% \mathrm{Cl})\end{array}$} \\
\hline & $\mathbf{N}$ & IR & $\mathbf{N}$ & IR & \\
\hline Eye disorders & 322 & 3.01 & 366 & 3.02 & $0.00(-0.45,0.46)$ \\
\hline Glaucoma & 29 & 0.26 & 33 & 0.26 & $0.01(-0.12,0.14)$ \\
\hline Vision blurred & 51 & 0.46 & 52 & 0.41 & $-0.06(-0.23,0.11)$ \\
\hline Gastrointestinal disorders & 1151 & 12.0 & 1553 & 14.9 & $2.44(1.42,3.46)^{*}$ \\
\hline Abdominal pain & 151 & 1.37 & 187 & 1.50 & $0.07(-0.24,0.38)$ \\
\hline Constipation & 135 & 1.22 & 196 & 1.57 & $0.34(0.04,0.64)^{*}$ \\
\hline Dry mouth & 142 & 1.29 & 373 & 3.06 & $1.65(1.28,2.03)^{*}$ \\
\hline Dyspepsia (including reflux) & 288 & 2.66 & 386 & 3.19 & $0.42(-0.02,0.86)$ \\
\hline Dysphagia & 19 & 0.17 & 22 & 0.17 & $-0.00(-0.10,0.10)$ \\
\hline Gl obstruction & 25 & 0.22 & 46 & 0.36 & $0.15(0.01,0.28)^{*}$ \\
\hline Gastroesophageal reflux & 203 & 1.86 & 286 & 2.33 & $0.37(-0.00,0.74)$ \\
\hline Stomatitis & 27 & 0.24 & 45 & 0.36 & $0.09(-0.05,0.23)$ \\
\hline Respiratory (upper) disorders & 1648 & 19.1 & 1985 & 20.6 & $0.75(-0.55,2.05)$ \\
\hline Laryngitis & 29 & 0.26 & 45 & 0.36 & $0.08(-0.05,0.22)$ \\
\hline Pharyngitis & 603 & 5.92 & 771 & 6.74 & $0.73(0.06,1.40)^{*}$ \\
\hline Metabolism and nutrition disorders & 531 & 5.08 & 547 & 4.61 & $-0.49(-1.07,0.10)$ \\
\hline Blood glucose increased & 175 & 1.60 & 173 & 1.39 & $-0.22(-0.54,0.09)$ \\
\hline Body temperature increased & 106 & 0.96 & 135 & 1.08 & $0.05(-0.21,0.31)$ \\
\hline Dehydration & 23 & 0.21 & 38 & 0.30 & $0.10(-0.03,0.23)$ \\
\hline Nervous system disorders & 774 & 7.58 & 907 & 7.92 & $-0.11(-0.86,0.64)$ \\
\hline Dizziness & 210 & 1.92 & 237 & 1.92 & $-0.10(-0.46,0.26)$ \\
\hline Headache & 282 & 2.60 & 346 & 2.83 & $-0.05(-0.48,0.39)$ \\
\hline Sleep disturbance & 150 & 1.36 & 193 & 1.56 & $0.16(-0.15,0.47)$ \\
\hline Syncope & 43 & 0.39 & 53 & 0.42 & $0.04(-0.13,0.20)$ \\
\hline Psychiatric disorders & 415 & 3.89 & 497 & 4.14 & $0.12(-0.40,0.65)$ \\
\hline Anxiety symptoms/fears & 152 & 1.38 & 168 & 1.35 & $-0.12(-0.42,0.18)$ \\
\hline Cognitive impairment & 50 & 0.45 & 61 & 0.48 & $0.02(-0.15,0.20)$ \\
\hline Confusion & 18 & 0.16 & 13 & 0.10 & $-0.07(-0.16,0.03)$ \\
\hline Depression & 140 & 1.26 & 175 & 1.40 & $0.14(-0.16,0.44)$ \\
\hline Insomnia & 121 & 1.10 & 171 & 1.38 & $0.26(-0.02,0.55)$ \\
\hline Restless/agitation & 12 & 0.11 & 12 & 0.09 & $-0.03(-0.12,0.05)$ \\
\hline Renal and urinary disorders & 258 & 2.37 & 294 & 2.38 & $-0.00(-0.40,0.39)$ \\
\hline Dysuria & 13 & 0.12 & 35 & 0.28 & $0.16(0.05,0.27)^{*}$ \\
\hline Renal failure & 56 & 0.50 & 60 & 0.47 & $-0.02(-0.20,0.16)$ \\
\hline Urinary retention & 27 & 0.24 & 48 & 0.38 & $0.14(-0.00,0.28)$ \\
\hline Urinary tract infection & 222 & 2.04 & 281 & 2.28 & $0.21(-0.17,0.58)$ \\
\hline
\end{tabular}

Abbreviations: $\mathrm{Cl}$, confidence interval; $\mathrm{n}$, number of patients with an event; IR, incidence rate (per 100 patient-years of time at risk); $\mathrm{RD}(95 \% \mathrm{Cl})$, rate difference $(95 \% \mathrm{Cl})$ per 100 patient-years of time at risk; terms used are composed of multiple MedDRA-preferred terms; ${ }^{p}>0.05$.

colleagues, additional data regarding lower respiratory, and anticholinergic events as well as fatal events associated with tiotropium $18 \mu \mathrm{g}$ daily delivered via the HandiHaler ${ }^{\circledR}$ device has been included in the present report. The clinical trial database of the 26 tiotropium HandiHaler ${ }^{\circledR}$ trials includes
7,865 placebo treated patients and 9,149 tiotropium treated patients, which corresponds to 10,578 and 11,958 patientyears of exposure respectively.

The 26 trial analyses show incidence rates that are lower in the tiotropium group relative to the placebo group for 
Table 9 Incidence rates and rate differences (tiotropium-placebo) per 100 patient-years for potential anticholinergic serious adverse events

\begin{tabular}{|c|c|c|c|c|c|}
\hline & \multicolumn{2}{|c|}{ Placebo $(n=7,865)$} & \multicolumn{2}{|c|}{ Tiotropium $(n=9,149)$} & \multirow{2}{*}{$\begin{array}{l}\text { Tiotropium-placebo } \\
\text { RD }(95 \% \mathrm{Cl})\end{array}$} \\
\hline & $\mathbf{N}$ & IR & $\mathbf{N}$ & IR & \\
\hline Eye disorders & 31 & 0.28 & 34 & 0.27 & $0.01(-0.13,0.14)$ \\
\hline Glaucoma & 1 & 0.01 & 2 & 0.02 & $0.01(-0.02,0.01$ \\
\hline Vision blurred & I & 0.01 & I & 0.01 & $-0.00(-0.02,0.02)$ \\
\hline Gastrointestinal disorders & 219 & 2.00 & 237 & 1.91 & $-0.07(-0.43,0.29)$ \\
\hline Abdominal pain & 26 & 0.23 & 23 & 0.18 & $-0.05(0.17,0.06)$ \\
\hline Constipation & 5 & 0.04 & 5 & 0.04 & $-0.00(0.06,0.05)$ \\
\hline Dry mouth & 0 & 0 & 0 & 0 & 0 \\
\hline Dyspepsia (including reflux) & 19 & 0.17 & 21 & 0.17 & $0.00(-0.10,0.11)$ \\
\hline Dysphagia & 4 & 0.04 & 4 & 0.03 & $-0.00(-0.05,0.04)$ \\
\hline Gl obstruction & 21 & 0.19 & 39 & 0.31 & $0.12(-0.00,0.25)$ \\
\hline Gastroesophageal reflux & 10 & 0.09 & 12 & 0.09 & $0.01(-0.07,0.08)$ \\
\hline Stomatitis & 0 & 0.00 & 2 & 0.02 & $0.02(-0.01,0.04)$ \\
\hline Respiratory (upper) disorders & 42 & 0.38 & 50 & 0.40 & $0.02(-0.14,0.18)$ \\
\hline Laryngitis & 1 & 0.01 & I & 0.01 & $-0.00(-0.02,0.02)$ \\
\hline Pharyngitis & 4 & 0.04 & I & 0.01 & $-0.03(-0.07,0.01)$ \\
\hline Metabolism and nutrition disorders & 65 & 0.58 & 65 & 0.51 & $-0.07(-0.26,0.12)$ \\
\hline Blood glucose increased & 15 & 0.13 & 26 & 0.20 & $0.06(-0.04,0.17)$ \\
\hline Body temperature increased & 8 & 0.07 & 13 & 0.10 & $0.03(-0.04,0.11)$ \\
\hline Dehydration & 12 & 0.11 & 20 & 0.16 & $0.05(-0.04,0.14)$ \\
\hline Nervous system disorders & $|7|$ & 1.55 & 186 & 1.49 & $-0.03(-0.35,0.28)$ \\
\hline Dizziness & 22 & 0.20 & 19 & 0.15 & $-0.04(-0.15,0.07)$ \\
\hline Headache & 4 & 0.04 & 5 & 0.04 & $0.01(-0.04,0.06)$ \\
\hline Sleep disturbance & 4 & 0.04 & 0 & 0.00 & $-0.04(-0.07,-0.00)$ \\
\hline Syncope & 12 & 0.11 & 24 & 0.19 & $0.08(-0.01,0.18)$ \\
\hline Psychiatric disorders & 48 & 0.43 & 36 & 0.28 & $-0.14(-0.30,0.10)$ \\
\hline Anxiety symptoms/fears & 8 & 0.07 & 4 & 0.03 & $-0.04(-0.10,0.02)$ \\
\hline Cognitive impairment & 9 & 0.08 & 5 & 0.04 & $-0.04(-0.11,0.02)$ \\
\hline Confusion & 3 & 0.03 & 2 & 0.02 & $-0.01(-0.05,0.03)$ \\
\hline Depression & 18 & 0.16 & 14 & 0.11 & $-0.05(-0.14,0.05)$ \\
\hline Insomnia & 1 & 0.01 & 0 & 0.00 & $-0.01(-0.03,0.01)$ \\
\hline Restless/agitation & 2 & 0.02 & 0 & 0.00 & $-0.02(-0.05,0.01)$ \\
\hline Renal and urinary disorders & 70 & 0.63 & 87 & 0.69 & $0.07(-0.14,0.28)$ \\
\hline Dysuria & 0 & 0.00 & 1 & 0.01 & $0.0 \mathrm{I}(-0.0 \mathrm{I}, 0.02)$ \\
\hline Renal failure & 26 & 0.23 & 38 & 0.30 & $0.07(-0.06,0.20)$ \\
\hline Urinary retention & 11 & 0.10 & 19 & 0.15 & $0.06(-0.03,0.15)$ \\
\hline Urinary tract infection & 22 & 0.20 & 31 & 0.24 & $0.05(-0.07,0.17)$ \\
\hline
\end{tabular}

Abbreviations: $\mathrm{Cl}$, confidence interval; $\mathrm{n}$, number of patients with an event; IR, incidence rate (per 100 patient-years of time at risk); $\mathrm{RD}(95 \% \mathrm{Cl})$, rate difference ( $95 \% \mathrm{Cl}$ ) per 100 patient-years of time at risk; terms used are composed of multiple MedDRA-preferred terms; $* P<0.05$.

overall adverse events, serious adverse events and all-cause mortality. There is no evidence to support an increase in adverse events, including fatal adverse events, under the system organ classes of cardiac or vascular disorders. Lower incidence rates with tiotropium relative to placebo were observed for a composite endpoint of major cardiovascular events. Additionally, lower rates were observed for lower respiratory tract events including exacerbations of COPD and 


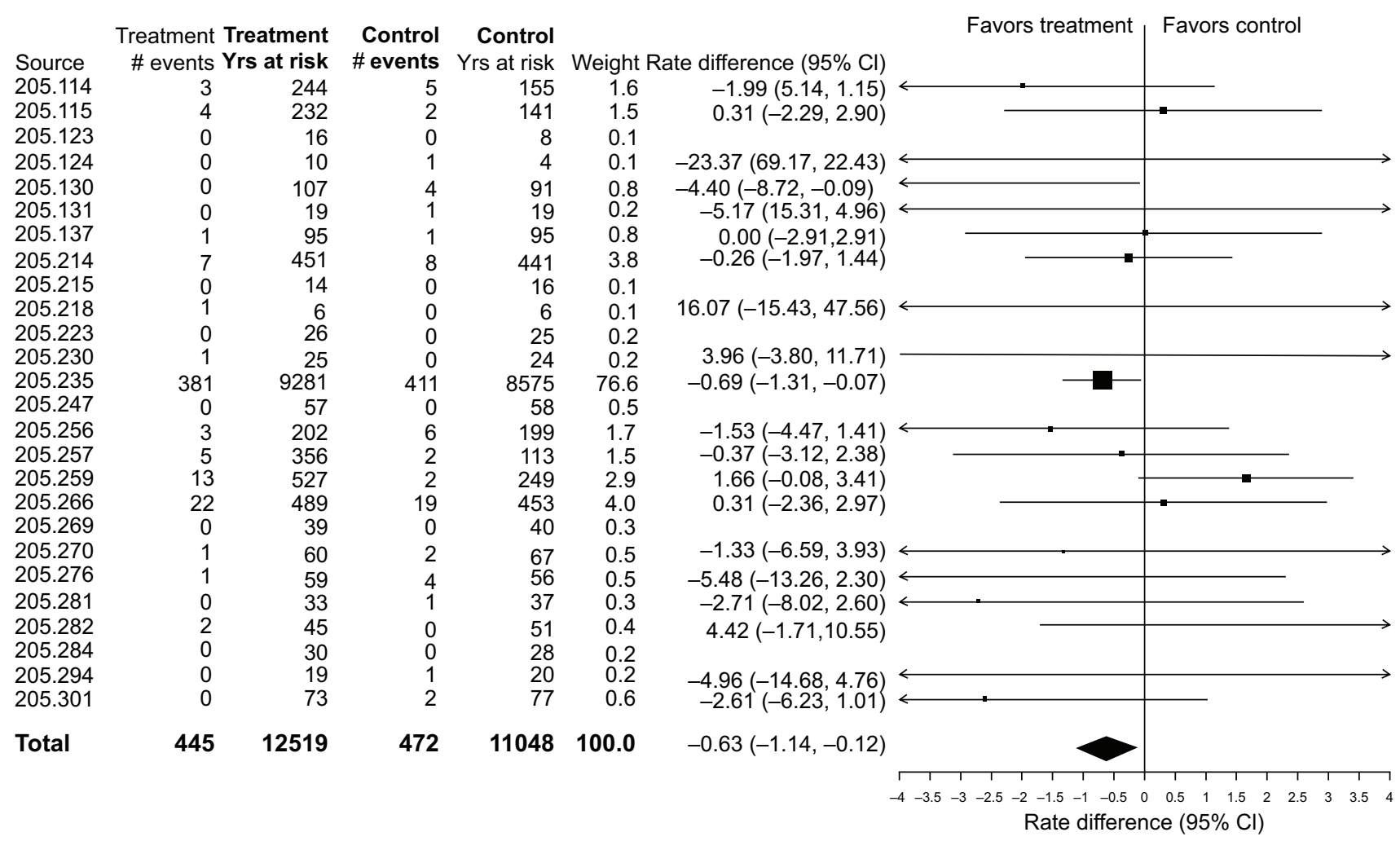

Figure I Incidence rates, rate differences (tiotropium-placebo), and $95 \%$ confidence intervals $(\mathrm{Cl})$ for all-cause mortality in 26 Tiotropium HandiHaler ${ }^{\circledR}$ trials (total and within each trial).

events reported as respiratory failure. For the above endpoints the upper limit of the CIs were below zero.

The analysis also confirms the association of tiotropium with several recognized anticholinergic effects such as dry mouth, constipation, dyspepsia and gastroesophageal reflux, and urinary difficulties. The increased size of the database results in more precise estimates of the incidence rate with tiotropium relative to the control group. The publication of the database results should provide additional information that improves the assessment of risks and benefits when prescribing tiotropium HandiHaler ${ }^{\circledR}$ to patients with COPD.

Previous published analyses have relied on incidence rate ratios or hazard ratios which reflect the relative risk of tiotropium to the comparator study group. The current report

Table 10 Incidence rates and rate differences (tiotropium-placebo) per 100 patient-years for fatal cases according to organ system with a frequency of at least $3 \%$ of the total number of fatal cases

\begin{tabular}{|c|c|c|c|c|c|}
\hline & \multicolumn{2}{|c|}{ Placebo $(n=7,865)$} & \multicolumn{2}{|c|}{ Tiotropium $(n=9,149)$} & \multirow{2}{*}{$\begin{array}{l}\text { Tiotropium-Placebo } \\
\text { RD }(95 \% \mathrm{Cl})\end{array}$} \\
\hline & $\mathbf{n}$ & IR & $\mathbf{n}$ & IR & \\
\hline Respiratory disorders (lower)** & 165 & 1.48 & 147 & 1.16 & $-0.30(-0.59,-0.00)^{*}$ \\
\hline Cardiac disorders & 105 & 0.94 & 88 & 0.69 & $-0.24(-0.47,-0.01)^{*}$ \\
\hline Respiratory disorders (other)** & 77 & 0.69 & 86 & 0.68 & $0.01(-0.20,0.23)$ \\
\hline General disorders and administration site conditions & 55 & 0.49 & 59 & 0.46 & $-0.01(-0.19,0.17)$ \\
\hline Neoplasms benign, malignant and unspecified*** & 52 & 0.46 & 47 & 0.37 & $-0.08(-0.24,0.09)$ \\
\hline Infections and infestations $* * *$ & 32 & 0.29 & 21 & 0.17 & $-0.11(-0.23,0.01)$ \\
\hline Nervous system disorders & 16 & 0.14 & 18 & 0.14 & $0.00(-0.09,0.10)$ \\
\hline
\end{tabular}

Notes: $* P<0.05 ; * * A l l$ primary system organ classes are defined by MedDRA with the exception of respiratory, thoracic, and mediastinal disorders which has been divided into three separate classes of respiratory system disorders: lower, upper, and other.***Preferred terms with a secondary relationship to MedDRA SOC Respiratory, thoracic and mediastinal disorders are not included.

Abbreviations: $\mathrm{Cl}$, confidence interval; $\mathrm{n}$, number of patients with an event; IR, incidence rate (per 100 patient-years of time at risk); RD ( $95 \% \mathrm{Cl}$ ), rate difference ( $95 \% \mathrm{Cl}$ ) per 100 patient-years of time at risk. 
Table I I Incidence rates and rate differences (tiotropium-placebo) per 100 patient-years for fatal cases by term with a frequency of at least 10 fatal cases

\begin{tabular}{|c|c|c|c|c|c|}
\hline & \multicolumn{2}{|c|}{ Placebo $(n=7,865)$} & \multicolumn{2}{|c|}{ Tiotropium $(n=9,149)$} & \multirow{2}{*}{$\begin{array}{l}\text { Tiotropium-placebo } \\
\text { RD }(95 \% \mathrm{Cl})\end{array}$} \\
\hline & $\mathbf{N}$ & IR & $\mathbf{n}$ & IR & \\
\hline COPD exacerbation & 68 & 0.61 & 65 & 0.51 & $-0.09(-0.28,0.10)$ \\
\hline Respiratory failure & 51 & 0.46 & 33 & 0.26 & $-0.19(-0.34,-0.03)^{*}$ \\
\hline Pneumonia & 36 & 0.32 & 33 & 0.26 & $-0.05(-0.19,0.09)$ \\
\hline Death & 28 & 0.25 & 36 & 0.28 & $0.04(-0.09,0.17)$ \\
\hline Myocardial infarction & 24 & 0.21 & 20 & 0.16 & $-0.05(-0.16,0.06)$ \\
\hline Lung neoplasm malignant & 19 & 0.17 & 21 & 0.17 & $0.00(-0.11,0.11)$ \\
\hline Cardiac arrest & 17 & 0.15 & 9 & 0.07 & $-0.08(-0.16,0.01)$ \\
\hline Sepsis & 17 & 0.15 & 8 & 0.06 & $-0.08(-0.17,-0.00)^{*}$ \\
\hline Cardiac failure & 10 & 0.09 & 14 & 0.11 & $0.02(-0.06,0.10)$ \\
\hline Sudden death & II & 0.10 & 12 & 0.09 & $-0.00(-0.08,0.08)$ \\
\hline Cardiac failure congestive & 10 & 0.09 & 6 & 0.05 & $-0.04(-0.11,0.02)$ \\
\hline
\end{tabular}

Abbreviations: $\mathrm{Cl}$, confidence interval; COPD, chronic obstructive pulmonary disease; $n$, number of patients with an event; IR, incidence rate (per I00 patient-years of time at risk); RD $(95 \% \mathrm{Cl})$, rate difference $(95 \% \mathrm{Cl})$ per 100 patient-years of time at risk; terms may consist of several preferred terms; $* P<0.05$.

discusses the results in terms of incident rate differences. Expressions of the relative risk assist in understanding the increased or decreased risk of a compound which can readily be understood and compared to other compounds (recognizing the distinct limitations of cross-study and even indication comparisons). There are several limitations with this approach. When the denominator is zero, the risk is infinite and cannot be numerically expressed. The public health impact of the increased or decreased risk cannot be easily discerned and small numbers of events can lead to exaggerated conclusions. For example, an event rate of one per million exposed to Drug A compared to two per million exposed to Drug B, leads to a conclusion of twice the risk with Drug B; however, without knowing the incidence rate per unit time, the public health consequences are uncertain. On the other hand, expression of an incidence rate difference of one per 1,000 patientyears exposed (or at risk) can lead to a more meaningful understanding. Nevertheless, in both situations, the availability of CIs is important to determine the reliability of the results.

While the majority of prospective, randomized, doubleblind clinical trials with inhaled anticholinergics have been conducted by Boehringer Ingelheim, several other studies warrant a brief discussion. The five-year Lung Health Study suggested an association of cardiovascular mortality with ipratropium although this seemed to be mainly in those patients not compliant with ipratropium. ${ }^{38,39} \mathrm{~A}$ two-year study found more deaths in the tiotropium-treated group compared to a group treated with salmeterol and fluticasone although equivalent effects were noted on exacerbations and more pneumonia was reported with combination therapy. Potential confounding and biases limits the interpretation beyond the primary exacerbation endpoint. ${ }^{40,41}$

Meta-analysis have yielded conflicting results for a variety of reasons but mainly related to early studies having incomplete data and inability to adjust for exposure due to differential discontinuation with higher discontinuation rates in the placebo groups. ${ }^{42,43}$ The limitations have been described in a previous publication of tiotropium data. ${ }^{10}$

Observational studies regarding mortality and inhaled anticholinergics have been reported; however, in general suffer from inability to adequately adjust for confounding by severity and diagnosis. ${ }^{44,45}$ As well, conflicting results have been reported, with increases, decreases and similar rates of events compared to control groups, which reflects differing methodologies but similar limitations. ${ }^{44-47}$ These issues limit such analyses to hypothesis generation and can be considered as being inferior to prospective controlled, double-blind studies where all patient level data is available.

Although the current study includes all patient level data and controls for differences in exposure between treatment groups, it is acknowledged that meta-analysis can have limitations given that data from different trials are being combined. As the trials were conducted using generally consistent inclusion and exclusion criteria, the same diagnostic criteria and nearly identical approaches to data collection, potential problems in combining studies have been minimized. ${ }^{10,48,55}$

In summary, the present report presents a robust and extensive analysis of over 17,000 patients participating in 
tiotropium HandiHaler ${ }^{\circledR}$ clinical trials and incorporation of all patient level data during treatment in a defined set of 26 randomized double-blind, placebo-controlled trials. The results indicate that tiotropium HandiHaler ${ }^{\circledR}$ does not increase the overall risk for fatal events and cardiovascular events. On the contrary, there appears to be a relatively consistent pattern or incidence rate ratios below 0 for mortality, cardiovascular events, and lower respiratory tract events with tiotropium HandiHaler ${ }^{\circledR} 18 \mu \mathrm{g}$ daily. Anticholinergic events are observed with tiotropium and the incidence rate differences reported may assist health care providers in their prescribing decisions. Based on the overall assessment of efficacy and safety, tiotropium HandiHaler ${ }^{\circledR}$ is considered to continue to exhibit a highly favorable benefit to risk profile in the treatment of COPD.

\section{Disclosures}

Dr Steven Kesten is a full-time employee of Boehringer Ingelheim. Dr Bart Celli has received research grants from GlaxoSmithKline, Boehringer Ingelheim, Forrest Pharmaceutical, and Aeris. Dr Celli has received honoraria from BoehringerIngelheim, GlaxoSmithKline, Almirall, AstraZeneca, Forrest, and Dey Pharmaceutical and has participated on advisory boards for Boehringer-Ingelheim, GlaxoSmithKline, Almirall, Astra Zeneca, Forrest, Dey Pharmaceutical, ALTANA. Marc Decramer is a member of the speaker's bureau of BoehringerPfizer. He is also a member of the advisory board of these companies. In addition, he is a member of the advisory board of Dompe Pharma SPA, GlaxoSmithKline and Nycomed. Dr Inge Leimer is a full-time employee of Boehringer Ingelheim. Dr Donald Tashkin has received research grants from Boehringer Ingelheim, AstraZeneca, Novartis, Dey Laboratories, GlaxoSmithKline, Almirall, Chiesi, Pfizer, and Forrest Pharmaceuticals. Dr Tashkin has received honoraria from Boehringer-Ingelheim, Pfizer, AstraZeneca, GlaxoSmithKline, and Dey Laboratories. He is a member on the advisory boards for Boehringer-Ingelheim, AstraZeneca, Novartis, Pfizer, and Dey Pharmaceuticals.

\section{References}

1. Curkendall SM, DeLuise C, Jones JK, et al. Cardiovascular disease in patients with chronic obstructive pulmonary disease, Saskatchewan Canada cardiovascular disease in COPD patients. Ann Epidemiol. 2006;16:63-70.

2. Anthonisen NR, Skeans MA, Wise RA, Manfreda J, Kanner RE, Connett JE; Lung Health Study Research Group. The effects of a smoking cessation intervention on 14.5-year mortality: a randomized clinical trial. Ann Intern Med. 2005;142:233-239.

3. Anthonisen NR. Prognosis in chronic obstructive pulmonary disease: results from multicenter clinical trials. Am Rev Respir Dis. 1989;140:S95-S99.
4. Domingo-Salvany A, Lamarca R, Ferrer M, et al. Health-related quality of life and mortality in male patients with chronic obstructive pulmonary disease. Am J Respir Crit Care Med. 2002;166:680-685.

5. Pinto-Plata VM, Cote C, Cabral H, Taylor J, Celli BR. The 6-min walk distance: change over time and value as a predictor of survival in severe COPD. Eur Respir J. 2004;23:28-33.

6. Hole DJ, Watt GCM, Davey-Smith G, Hart CL, Gillis CR, Hawthorne VM. Impaired lung function and mortality risk in men and women: findings from the Renfrew and Paisley prospective population study. BMJ. 1996;313:711-715.

7. Rabe KR, Hurd S, Anzueto A, et al. Global Strategy for the Diagnosis, Management, and Prevention of Chronic Obstructive Pulmonary Disease: GOLD Executive Summary. Am J Respir Crit Care Med. 2007; 176:532-555.

8. American Thoracic Society. Standards for the diagnosis and care of patients with chronic obstructive pulmonary disease (COPD). Am J Respir Crit Care Med. 1995;152:S77-S120.

9. Kesten S, Jara M, Wentworth C, Lanes S. Pooled clinical trial analysis of tiotropium safety. Chest. 2006;130:1695-1703.

10. Celli B, Decramer M, Leimer I, Vogel U, Kesten S, Tashkin D. Cardiovascular safety of tiotropium in patients with COPD. Chest. Jul 10. [Epub ahead of print].

11. Casaburi R, Mahler DA, Jones PW, et al. A long-term evaluation of once-daily tiotropium in chronic obstructive pulmonary disease. Eur Respir J. 2002;19:217-224.

12. Calverley PM, Lee A, Towse L, Witek TJ Jr, Kesten S. Effect of tiotropium bromide on circadian variation in airflow limitation in chronic obstructive pulmonary disease. Thorax. 2003;58:855-860.

13. McNicholas WT, Calverley PMA, Lee A, Edwards JC; on behalf of the Tiotropium Sleep study in COPD investigators. Effects of longacting anticholinergic therapy (tiotropium) on oxygen saturation and sleep quality in adults with severe COPD. Eur Respir J. 2004;23: 825-831.

14. Brusasco V, Hodder R, Miravitlles M, et al. Health outcomes following treatment for six months with once daily tiotropium compared with twice daily salmeterol in patients with COPD. Thorax. 2003;58:399-404.

15. O’Donnell D, Flüge T, Gerken F, et al. Effects of tiotropium on lung hyperinflation, dyspnoea and exercise tolerance in COPD. Eur Respir J. 2004;23:832-840.

16. Dusser D, Bravo ML, Iacono P. The effect of tiotropium on exacerbations and airflow in patients with COPD. Eur Respir J. 2006;27:547-555.

17. Verkindre C, Bart F, Aguilaniu B, et al. The effect of tiotropium on hyperinflation and exercise capacity in chronic obstructive pulmonary disease. Respiration. 2006;73:420-427.

18. Celli B, ZuWallack R, Wang S, Kesten S. Improvement in resting inspiratory capacity and hyperinflation with tiotropium in COPD patients with increased static lung volumes. Chest. 2003;124:1743-1748.

19. Maltais F, Hamilton A, Marciniuk D, et al. Improvements in symptomlimited exercise performance over $8 \mathrm{~h}$ with once-daily tiotropium in patients with COPD. Chest. 2005;128:1168-1178.

20. Casaburi R, Kukafka D, Cooper CB, Witek TJ, Kesten S. Improvement in exercise tolerance with the combination of tiotropium and pulmonary rehabilitation in patients with COPD. Chest. 2005;127: 809-817.

21. Tashkin DP, Celli B, Senn S, et al; for the UPLIFT investigators. A four year trial of tiotropium in patients with chronic obstructive pulmonary disease. N Engl J Med. 2008;359:1543-1554.

22. Ambrosino N, Foglio K, Balzano G, Paggiaro PL, Lessi P, Kesten S; Tiotropium Multicentric Italian Study Group. Tiotropium and exercise training in COPD patients: effects on dyspnea and exercise tolerance. Int J Chron Obstruct Pulmon Dis. 2008;3(4):771-780.

23. Tonnel AB, Perez T, Grosbois JM, Verkindre C, Bravo ML, Brun M; TIPHON study group. Effect of tiotropium on health-related quality of life as a primary efficacy endpoint in COPD. Int J Chron Obstruct Pulmon Dis. 2008;3:301-310. 
24. Beeh KM, Beier J, Buhl R, Stark-Lorenzen P, Gerken F, Metzdorf N; ATEM-Studiengruppe. [Efficacy of tiotropium bromide (Spiriva) in patients with chronic-obstructive pulmonary disease (COPD) of different severities]. Pneumologie. 2006;60:341-346.

25. Chan CKN, Maltais F, Sigouin S, Haddon JM, Ford G. A randomized controlled trial to assess the efficacy of tiotropium in Canadian patients with chronic obstructive pulmonary disease. Can Respir J. 2008; 14:465-472.

26. Niewoehner DE, Rice K, Cote C, et al. Prevention of exacerbations of chronic obstructive pulmonary disease with tiotropium, a once-daily inhaled anticholinergic bronchodilator. Ann Intern Med. 2005;143:319-326.

27. Powrie DJ, Wilkinson TMA, Donaldson GC, et al. Effect of tiotropium on sputum and serum inflammatory markers and exacerbations in chronic obstructive pulmonary disease. Eur Respir J. 2007;30:472-478.

28. Freeman D, Lee A, Price D. Efficacy and safety of tiotropium in COPD patients in primary care-the SPiRiva Usual CarE (SPRUCE) study. Respir Res. 2007;8:45.

29. Johansson G, Lindberg A, Romberg K, Nordstrom L, Gerken F, Roquet A. Bronchodilator efficacy of tiotropium in patients with mild to moderate COPD. Prim Care Respir J. 2008;17:169-175.

30. Moita J, Bárbara C, Cardoso J, et al. Tiotropium improves $\mathrm{FEV}_{1}$ in patients with COPD irrespective of smoking status. Pulm Pharmacol Ther. 2008;21:146-151.

31. Covelli H, Bhattacharya S, Cassino C, Conoscenti C, Kesten S. Absence of electrocardiographic findings and improved function with daily tiotropium in patients with chronic obstructive pulmonary disease. Pharmacotherapy. 2005;25:1708-1718.

32. Criner GJ, Sharafkhaneh A, Player R, et al. Efficacy of tiotropium inhalation powder in African-American patients with chronic obstructive pulmonary disease. COPD. 2008;5:35-41.

33. Magnussen H, Bugnas B, van Noord J, Schmidt P, Gerken F, Kesten S. Spirometric improvements with tiotropium in COPD patients with concomitant asthma. Respir Med. 2008;102:50-56.

34. American Thoracic Society. Standardization of spirometry - 1994 update. Am J Respir Crit Care Med. 1995;152:1107-1136.

35. Greenland S, Robins J. Estimation of a common effect parameter from sparse follow-up data. Biometrics. 1985;41:55-68.
36. Rothman KJ, Greenland S. Measures of disease frequency. In: Rothman KJ, Greenland S (editors). Modern Epidemiology, 2nd ed. Philadelphia, PA: Lippincott-Raven Publishers; 1998. pp. 29-46.

37. Reis IM, Hirji KF, Afifi AA. Exact and asymptotic tests for homogeneity in several 2 x 2 tables. Stat Med. 1999;18:893-906.

38. Anthonisen NR, Connett JE, Enright PL, Manfreda J; Lung Health Study Research Group. Hospitalizations and mortality in the Lung Health Study. Am J Respir Crit Care Med. 2002;166:333-339.

39. Lanes S, Golish W, Mikl J. Ipratropium and Lung Health Study (letter). Am J Rev Respir Crit Care Med. 2003;167(7):801.

40. Wedzicha JA, Calverley PMA, Seemungal TA, Hagan G, Ansari Z, Stockley RA, INSPIRE Investigators. The prevention of COPD exacerbations by salmeterol/fluticasone propionate or tiotropium bromide. Am J Respir Crit Care Med. 2008;177:19-26.

41. Lanes SF, Jara M. The INSPIRE study: influence of prior use and discontinuation of inhaled corticosteroids. Am J Resp Crit Care Med. 2008; 178:543-544.

42. Singh S, Loke YK, Furberg CD. Inhaled anticholinergics and risk of major adverse cardiovascular events in patients with chronic obstructive pulmonary disease. JAMA. 2008;300:1439-1450.

43. Salpeter SR. Bronchodilators in COPD: impact of B-agonists and anticholinergics on severe exacerbations and mortality. Int J COPD. 2007;2:11-18.

44. Lee TA, Pickard AS, Au DH, Bartle B, Weiss KB. Risk of death associated with medications for recently diagnosed chronic obstructive pulmonary disease. Ann Intern Med. 2008;149:380-390.

45. Jara M, Lanes SF, Wentworth C 3rd, May C, Kesten S. Comparative safety of long-acting inhaled bronchodilators: a cohort study using the UK THIN primary care database. Drug Saf. 2007;30:1151-1160.

46. de Luise C, Lanes SF, Jacobsen J, Pedersen L, Sorensen HT. Cardiovascular and respiratory hospitalizations and mortality among users of tiotropium in Denmark. Pharmacoepidemiology. 2007;22:267-272.

47. Gershon A, Wang L, To T, Luo J, Upshur RE. Survival with tiotropium compared to long-acting beta-2-agonists in chronic obstructive pulmonary disease. COPD. 2008;5:229-234.

48. Kesten S, Plautz M, Piquette CA, Habib MP, Niewoehner DE. Premature discontinuation of patients: a potential bias in COPD clinical trials. Eur Respir J. 2007;30:898-906.
International Journal of COPD

\section{Publish your work in this journal}

The International Journal of COPD is an international, peer-reviewed journal of therapeutics and pharmacology focusing on concise rapid reporting of clinical studies and reviews in COPD. Special focus is given to the pathophysiological processes underlying the disease, intervention programs, patient focused education, and self management protocols.

\section{Dovepress}

This journal is indexed on PubMed Central, MedLine and CAS. The manuscript management system is completely online and includes a very quick and fair peer-review system, which is all easy to use. Visit http://www.dovepress.com/testimonials.php to read real quotes from published authors. 